\title{
Research on Medium and Long Term Energy Demand Forecast under New Urbanization
}

\author{
Bao-guo SHAN \\ State Grid Energy Research Institution, \\ Beijing, 102209, China
}

\author{
Ding MA \\ State Grid Energy Research Institution, \\ Beijing, 102209, China
}

\author{
Cheng-long ZHANG* \\ State Grid Energy Research Institution, \\ Beijing, 102209, China \\ e-mail: zhangchenglong@sgeri.sgcc.com.cn
}

\begin{abstract}
The "national new urbanization plan (2014 - 2020)" was promulgated in China in 2014, will have a profound impact on medium and long term energy demand in China. This paper put forward economy-energy-environmental model system, set up two scenarios (baseline scenario and new urbanization scenario), analyzed and forecast the long-term China's energy demand and structure. The model system includes Macroeconomic Forecast model (MEF), Computable General Equilibrium model (CGE), Final Energy Demand Forecast model (FEDF), Energy System Optimization model (ESO). Besides, a data-transmission mechanism was established. Scenario analysis results show that the model system can simulate the impact of the new urbanization policies on economy, energy, analyze the relationship between economy and energy, and then forecast the medium and long term energy demand. New urbanization will make energy consumption less and energy structure cleaner, relative to the baseline scenario. In 2030primary energy demand will reach 5490million tons coal equivalent in new urbanization scenario, 630 million tons coal equivalent less than in baseline scenario.
\end{abstract}

Keywords-New urbanization; Model system; Computable general equilibrium model; Energy demand.

\section{INTRODUCTION}

In 2014, "new urbanization plan (2014 - 2020)" was issued in China. According to the plan, urbanization development mode would change. Firstly, the level and quality of urbanization will be steadily improved. The resident population urbanization rate will reach about $60 \%$ in 2020, 7.4 percentage points higher than that in 2014, and strive to make about 100 million of agricultural population settle in towns. Secondly, scientific and rational macro urbanization layout will be constructed according to the carrying capacity of resources and environment. Thirdly, green development, cycle development and low carbon development will strengthen environmental protection and ecological restoration. Fourthly, such urban basic public services as compulsory education, employment services, basic pension, and basic health care will cover all the resident population.

The connotation of new urbanization is rich, involving environmental protection, population transfer, industrial development, layout optimization and so on, which challenge the research of the relationship between energy development and new urbanization. Thus, it is necessary to innovate research methods, to simulate the new situation. This paper analyzes the main factors that affect energy demand and supply, and establishes analysis and forecast model, and forecasts the total supply and demand, structure and layout under new urbanization.

\section{ENERGY DEMAND ANALYSIS MODEL SYSTEMS UNDER NEW URBANIZATION MODE}

According to the interaction mechanism between the new urbanization and the energy supply and demand, a model systems are constructed, which includes 4 modules(shown in Fig.1): Macroeconomic Forecast model (MEF), Computable General Equilibrium model (CGE), Final Energy Demand Forecast model (FEDF), Energy System Optimization model (ESO). Besides, a data-transmission mechanism is established [1].

Macroeconomic Forecast model (MEF) [2], a vector auto-regression econometrics model, can forecast economic growth, industrial structure under given urbanization scenarios, provide input for CGE model and FEDF model. The model analyzes and forecast the relationship between such factors as urbanization rate, city public services and production factors such as labor, investment, total factor productivity, and then quantitatively predict long-term GDP and the value-added of three major industries.

Computable General Equilibrium model (CGE) [3][4], quantitatively analyze the industrial restructuring and upgrading of more detailed subdivided industries, and provide input for FEDF model. The model can simulate the effect of finance, price, technology, industrial policy on macroeconomic and industries. The model includes 175 kinds of products, 162 institutes (agriculture department and energy department are subdivided on the basis of the 2007 input-output data of 135 departments), three input factors (capital, labor and land), six economic entities (production, households, investment, government, overseas and inventory) and eight circulation input factors (marine and air transportations, railways, highways, pipeline transportations, 
insurance, trade and warehouse storage). The basic data come from 2012 China's input-output data.

Final Energy Demand Forecasting model (FEDF) quantitative analyzes the main final energy varieties demand to meet the industry development and residential living. Firstly, different methods are used to forecast the total energy consumption of different industries, energy consumption per unit of product for high energy-extensive industries, energy consumption per unit of turnover volume for transportation industry, energy consumption per unit of value-added for other industries. Secondly, build a series of regression equation between energy relative prices of different varieties and share in terminal energy consumption to forecast energy share of every industries. For those industries that there are not strong relationships between energy relative price and energy share, or structural change is steady, use trend extrapolation method to forecast energy share. Thirdly, terminal energy demand for each energy varieties can be calculated, based on total final energy demand and demand and final energy demand structures.

Energy System Optimization model (ESO) is used to analyze the total energy supply, energy structure, investment cost and so on, based on the forecast results of final energy demand. The model is developed by State Grid Energy Research Institution independently. It can minimize system cost as optimization goal, considering the constraints of resource, environment, policies and technology etc. and ensure the balancing of energy supply and demand.

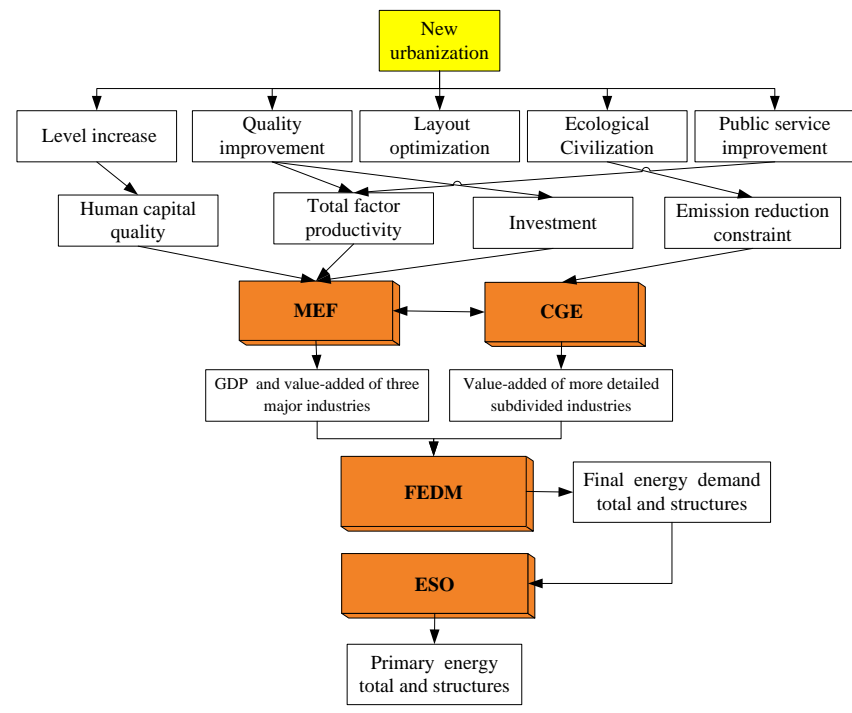

Figure 1. Energy demand analysis model framework under new urbanization mode

\section{SCENARIO DESIGN}

\section{A. Selecting a Template}

The paper designs baseline scenario and new urbanization scenario considering such factors as economic development, industrial structure adjustment, energy technology, and regional layout, shown in Table 1.
In baseline scenario, the current urbanization development mode will continue, energy demand will increase by the recent trend.

In new urbanization scenario, economic development mode transformation will accelerate, industrial structural adjustment will accelerate, urbanization development will speed up, highly energy-extensive industries transfer from east to west will speed up, wind power, solar energy, distributed energy will develop more rapidly, energy efficiency is greatly improved, energy conservation and energy structure adjustment will be strengthened, as the result of market and policy. Table 1 lists judgment and hypothesis of the key factors in the two scenarios.

TABLE I. KEY FACTORS IN BASELINE SCENARIO AND NEW URBANIZATION SCENARIO

\begin{tabular}{|c|c|c|c|}
\hline Type & $\begin{array}{c}\text { Key } \\
\text { factors }\end{array}$ & Baseline scenario & $\begin{array}{c}\text { New } \\
\text { urbanization } \\
\text { scenario }\end{array}$ \\
\hline \multirow{3}{*}{$\begin{array}{l}\text { Econo } \\
\text { mic and } \\
\text { social } \\
\text { develop } \\
\text { ment }\end{array}$} & $\begin{array}{l}\text { GDP } \\
\text { growth }\end{array}$ & $\begin{array}{l}\text { The annual average } \\
\text { growth rate during the } \\
13 \text { th Five Year Plan is } \\
7.0 \% \text {, while it will be } \\
5.5 \% \text { in the period from } \\
2020 \text { to } 2030 \text {. }\end{array}$ & $\begin{array}{c}\text { The same as } \\
\text { baseline } \\
\text { scenario. }\end{array}$ \\
\hline & $\begin{array}{l}\text { Urbanli } \\
\text { zation }\end{array}$ & $\begin{array}{l}\text { Urbanliazation is promted } \\
\text { steadily. The } \\
\text { urbanlization rate will be } \\
60 \% \text { in } 2020 \text { and } 70 \% \text { in } \\
2030 .\end{array}$ & $\begin{array}{l}\text { Urbanliazation } \\
\text { rate will } \\
\text { increase. The } \\
\text { urbanlization rate } \\
\text { will be } 61 \% \text { in } \\
2020 \text { and } 72 \% \text { in } \\
2030 .\end{array}$ \\
\hline & $\begin{array}{c}\text { Populat } \\
\text { ion }\end{array}$ & $\begin{array}{l}\text { The population grows } \\
\text { slowly.From the forecast } \\
\text { data of UN, the } \\
\text { population will be } 14.19 \\
\text { hundred million in } 2020 \\
\text { and } 14.67 \text { hundred million } \\
\text { in } 2030 .\end{array}$ & $\begin{array}{c}\text { The same as } \\
\text { baseline } \\
\text { scenario. }\end{array}$ \\
\hline \multirow{2}{*}{$\begin{array}{l}\text { Structu } \\
\text { re } \\
\text { convers } \\
\text { ion }\end{array}$} & $\begin{array}{l}\text { Invest } \\
\text { mentst } \\
\text { ructur } \\
\text { es }\end{array}$ & $\begin{array}{l}\text { Industrial structures } \\
\text { optimize, and the } \\
\text { investment proportion } \\
\text { ofstrategic } \begin{array}{r}\text { emerging } \\
\text { industries and modern } \\
\text { service } \\
\text { increase. }\end{array}\end{array}$ & $\begin{array}{l}\text { The investment } \\
\text { proportion of } \\
\text { strategic } \\
\text { emerging } \\
\text { industries and } \\
\text { modern service } \\
\text { industries } \\
\text { increase further. }\end{array}$ \\
\hline & $\begin{array}{l}\text { Industri } \\
\text { al } \\
\text { struct } \\
\text { ures }\end{array}$ & $\begin{array}{l}\text { Industrialization will be } \\
\text { basically realized in } 2020 \text {. } \\
\text { After } 2020 \text {, the proportion } \\
\text { of the second industry } \\
\text { will decrease steadily and } \\
\text { that of the third industry } \\
\text { will continue to rise. }\end{array}$ & $\begin{array}{l}\text { Compared with } \\
\text { the baseline } \\
\text { scenario, the } \\
\text { proportion of the } \\
\text { second industry } \\
\text { is smaller while } \\
\text { that of the third } \\
\text { industry is larger } \\
\text { in level years. }\end{array}$ \\
\hline
\end{tabular}

\section{SIMULATION RESULTS}

\section{A. Total Energy Demand}

Energy demand will continue to grow before 2030, and the growth rate will slow down after 2020, with industrialization basically completed. As shown in Fig.2, the new urbanization will save a lot of energy demand, relative to the baseline scenario. In new urbanization scenario, in 
2020, 2030, primary energy demand will reach 4730, 5490milliontons coal equivalent, 300, 630 million tons coal equivalent less than in baseline scenario; primary energy demand will increase $3.5 \%, 1.5 \%$ annuallyin average in 2016-2020, 2020-2030 respectively, 0.8 and 0.5 percentage points lower than that in baseline scenario.

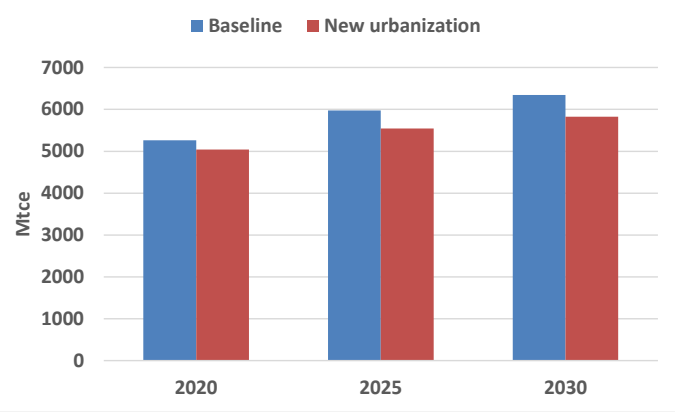

Figure 2. China primary energy demand in $2020-2030$

\section{B. Energy Demand Structure}

In 2030, with technical progress, the cost of large-scale development and utilization of natural gas, wind power, solar and other renewable energy will decline substantially, will promote energy structure more clean, as shown in Fig.3.

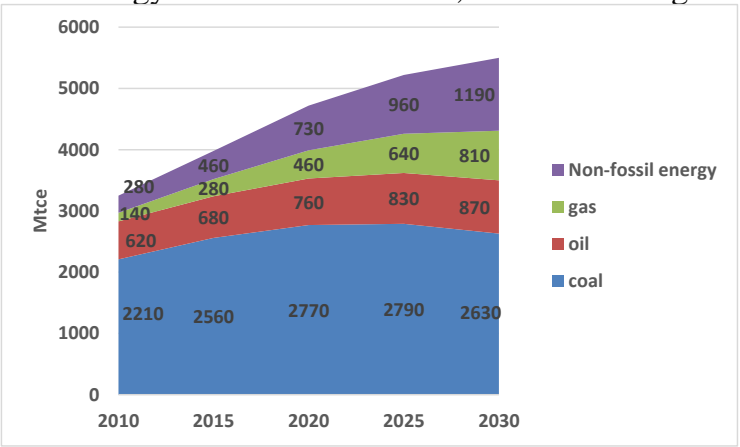

Figure 3. Energy demand of main kinds of primaryenergy in new urbanization scenario

With environmental capacity constraints, coal consumption growth will gradually tend to zero or even negative in 2020 , but coal will still be the first major energy variety by 2030 . Under new urbanization scenarios, coal consumption will reach 2770, 2630 million tons coal equivalent in 2020, 2030 respectively, about 58.6\%, 47.8\% in total primary energy, $0.1,1.5$ percentage points lower than that in baseline scenario.

Oil consumption will continuously grow before 2030, due to the strong demand from transportation industry, but the proportion in total energy consumption will decline. In new urbanization scenarios, oil consumption will reached 760, 870 million tons coal equivalent in 2020, 2030 respectively, about $16.1 \%, 15.8 \%$ in total energy consumption, $0.3,0.1$ percentage points lower than that in baseline scenario.

With the substantial increase in domestic and imported natural gas supply capacity, natural gas consumption will continue to grow rapidly before 2020, and then slow down after 2020 due to increasing basic quantity. Under new urbanization scenarios, natural gas consumption will reach 460, 810million tons coal equivalent in 2020, 2030 respectively, accounting for $9.8 \%, 14.7 \%$ in total energy consumption, $0.1,0.4$ percentage points higher than that in baseline scenario.

With large-scale development and utilization of hydropower, wind power, solar energy and other non-fossil energy, non-fossil energy consumption will grow rapidly, become the second energy in primary energy beyond oil. In new urbanization scenarios, non-fossil energy consumption will reach 730, 1190 million tons coal equivalent in 2020, 2030 respectively, accounting for $15.4 \%$, 21.6\% in total energy consumption, $0.3,1.1$ percentage points higher than that in baseline scenarios.

\section{CONCLUSIONS}

Firstly, the model system established in this paper can simulate the impact of the new urbanization policies on economy, energy, analyze the relationship between economy and energy, and then forecast the medium and long term energy demand. Secondly, one of shortages of the model systems using soft connection is that transferring data between models costs lots of time. Thirdly, new urbanization will make energy consumption less and energy structure cleaner, relative to the baseline scenario.

\section{REFERENCES}

[1] Cheng-long Zhang, Ji-feng Li, A-ling Zhang et al, Journal of Tsinghua University (Natural Science edition). 2011, 51(2):234-240. (in Chinese)

[2] Zhao-guang Hu, Bao-guo Shan et al. Simulation experiment of power supply and demand: soft science laboratory based on intelligent engineering(China Electric Power Press, Beijing,2009).(in Chinese)

[3] Ming-yong Lai, Shu-jin Zhu. Regional trade liberalization: Information center computable general equilibrium model. (Economic Science Press, Beijing,2008). (in Chinese)

[4] Dixon P B, Rimmer M T. Dynamic General Equilibrium Modeling for Forecasting and Policy: A Practical Guide and Documentation of Monash(Holland, Amsterdam: North-Holland, 2002.f)

[5] Wen-ying Chen, Energy Policy, 2005, 33(7):885-896. (in Chinese)

[6] Schafer A, Jacoby H D, Energy Journal, 2006, Sp. Iss. 2 (2): 171-177

[7] Ji-feng Li, Ya-xiong Zhang, Wen-qing Pan., Economic Perspectives, 2010, (5):47-51. (in Chinese)

[8] Qin Zhang, Ji-feng Li, Ya-xiong Zhang, China Economic and Trade, 2010, (11):21-24. (in Chinese)

[9] Yu Liu, Ya-xiong Zhang, Hai-sen Zhang, International Business, 2011, (1):5-14. (in Chinese)

[10] Mikhail Simonov, Riccardo Zich, Marco Mussetta, "Information Processing in Smart Grids and Consumption Dynamics", Information Retrieval and Mining in Distributed Environments, Volume 324 of the series Studies in Computational Intelligence pp 267-286. DOI: 10.1007/978-3-642-16089-9_15

[11] S. Leva, A. Dolara, F. Grimaccia, M. Mussetta, E. Ogliari, "Analysis and validation of 24 hours ahead neural network forecasting of photovoltaic output power", Mathematics and Computers in Simulation, Volume 131, January 2017, Pages 88-100, ISSN 03784754, http://dx.doi.org/10.1016/j.matcom.2015.05.010. 